Article

\title{
Life Cycle Assessment (LCA) of the Use of Metallurgical Process Gas for Heat and Electricity, Combined with Salt Removal from Discarded Water
}

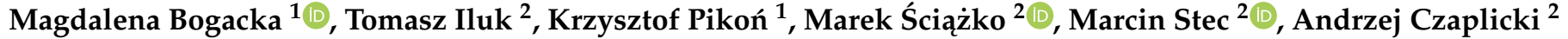 \\ and Agata Wajda 1,*(D) \\ 1 Department of Technologies and Installations for Waste Management, Faculty of Energy and Environmental \\ Engineering, Silesian University of Technology, 44-100 Gliwice, Poland; Magdalena.Bogacka@polsl.pl (M.B.); \\ Krzysztof.Pikon@polsl.pl (K.P.) \\ 2 Institute for Chemical Processing of Coal, 41-803 Zabrze, Poland; tiluk@ichpw.pl (T.I.); \\ msciazko@ichpw.pl (M.Ś.); mstec@ichpw.pl (M.S.); aczaplicki@ichpw.pl (A.C.) \\ * Correspondence: Agata.Wajda@polsl.pl; Tel.: +48-32-237-13-21
}

check for updates

Citation: Bogacka, M.; Iluk, T.; Pikoń, K.; Ściążko, M.; Stec, M.; Czaplicki, A.; Wajda, A. Life Cycle Assessment (LCA) of the Use of Metallurgical Process Gas for Heat and Electricity, Combined with Salt Removal from Discarded Water. Sustainability 2022 14, 1205. https://doi.org/10.3390/ su14031205

Academic Editor: Andrius Plepys

Received: 29 November 2021

Accepted: 11 January 2022

Published: 21 January 2022

Publisher's Note: MDPI stays neutral with regard to jurisdictional claims in published maps and institutional affiliations.

Copyright: (C) 2022 by the authors. Licensee MDPI, Basel, Switzerland. This article is an open access article distributed under the terms and conditions of the Creative Commons Attribution (CC BY) license (https:// creativecommons.org/licenses/by/ $4.0 /)$.

\begin{abstract}
The subject of the article is the assessment of the environmental impact of the technology concerning the use of low-quality post-process gas for the production of electricity and heat, along with the treatment of post-process wastewater. This assessment was carried out based on the results of the full life cycle assessment (LCA) analysis. The presented technology is based on the energetic use of low-quality process gases in a reciprocating engine for the production of electricity and heat in cogeneration with the use of heat in the wastewater treatment system. The article presents the adopted assumptions and the results of the LCA analysis for the RECLEG technology developed specifically for a zinc smelter. The aim of the analysis was to check whether the developed technology has a positive impact on the environment. The LCA analysis was performed using the ReCiPe methodology, which is one of the most frequently used methodologies in this field due to the possibility of observing the environmental impact in a full range of different environmental aspects. At the same time, the analysis also allows the results to be presented in three general impact categories: human health, ecosystem and natural resources, which are easier to interpret. By converting the waste post-process gas into electricity and heat, it is seen that this has a positive impact on the environment. Especially due to the waste nature of the source, which is the post-process gas. Each reduction of gas is potentially beneficial for the environment and, in addition, a replacement effect can be observed, because the gas was previously burned in a flare, where it additionally emitted exhaust gases, sent directly to the atmosphere. Moreover, the RECLEG technology combines post-process wastewater treatment, which has a positive effect on water management, and makes the process even more environmentally friendly.
\end{abstract}

Keywords: LCA; RECLEG technology; post-process gas; chlorine ions; emission reduction; effective generation

\section{Introduction}

The legal regulations introduced in recent years, as well as the growing concern for the natural environment, have contributed to taking actions aimed at implementing innovative solutions in the industry, as well as optimising existing technological processes. The transformation of the economy towards sustainability has been defined by numerous international documents. Actions in this area are undertaken, among others, by the United Nations, which developed the document The 2030 Agenda for Sustainable Development [1], and the European Union, which is working on a coherent policy with the member states in this area. An example of such action is the guidelines for the implementation of the circular economy in the form of a document [2]. An important issue in this regard is the 
integration and optimisation of individual processing nodes in the existing plants, which, by combining them and applying modern solutions, allows to reduce the impact on the natural environment, recover raw materials, as well as achieve higher energy efficiency indicators, enabling an increase in the economic profitability of production [3,4].

The implementation of optimisation solutions should be preceded by an analysis, including an environmental impact assessment. Life Cycle Assessment (LCA) is a methodology for assessing environmental performance. It can be determined that it is the most commonly used universal tool for quantifying the environmental impact of individual products, processes and services [5-9]. The work [6] also shows additional possibilities for using the LCA methodology in the context of supporting the decision-making process of manufacturing companies that plan to implement business models in line with the circular economy idea. The LCA can also demonstrate environmental hotspots with the process or compare several processes or products. The authors of [10], based on the British experience, have identified places in the solar-powered latent heat thermal energy storage system that require improvement. Noel et al. in [11] made a comparison of two chemical compounds that can potentially be used, inter alia, in the storage of thermal energy, in terms of environmental impact.

Life Cycle Assessment analysis is used in many similar projects, which were considered by [12,13]. The authors of the study [13] developed an environmental analysis of the operating treatment plant using $\mathrm{ReCiPe}$, which allowed them to identify points that can be improved in the technology. Skoczko et al. [14] compared two wastewater treatment technologies in analogous industrial plants, thanks to which a more advantageous solution was specified. A different approach to this issue can be seen in the works [15-17], which emphasise the standardisation of the LCA methodology used in wastewater treatment plants. This is an important aspect due to the possibility of using the results of LCA analysis by decision-makers, which requires the transparency of the analysis and the use of its appropriate parameters [18]. Similar postulates and attempts to develop a coherent approach in the LCA methodology can be seen in the analyses of the operation of energygenerating installations $[19,20]$.

One of such activities is the implementation of a Polish zinc smelter. The results of an R\&D project, entitled "Effective generation of electric power from post-process waste gases with a simultaneous reduction of chlorine ion emissions into the environment-RECLEG", aims to integrate energy and environmental management in order to use post-process gas to produce electricity and heat while treating industrial wastewater. The technology is an attempt to solve the problem involving the high energy demand of wastewater treatment plants. Gas, as a by-product of the zinc smelter process, is used in the wastewater treatment process. The technological diagram of the proposed solution is shown in Figure 1.

The technology is based on the use of low calorific value post-process gas with natural gas, the mixture of which is co-combusted in a reciprocating engine to produce electricity and heat in cogeneration, and the excess heat generated is effectively used in the postprocess water treatment plant. The technology will enable the production of electricity, heat, the recovery of zinc and lead dissolved in wastewater, the returning of clean water to the process, a reduction of the content of heavy metals and chlorine ions in discharged water, and the production of industrial grade salt. The aim of this study is to obtain reliable information and analysis regarding the environmental impact of the designed technological solution. The LCA analysis performed using the ReCiPe methodology was used for this purpose, which is one of the more frequently used methodologies in this field due to the possibility of observing the environmental impact in the full range of various environmental aspects. 


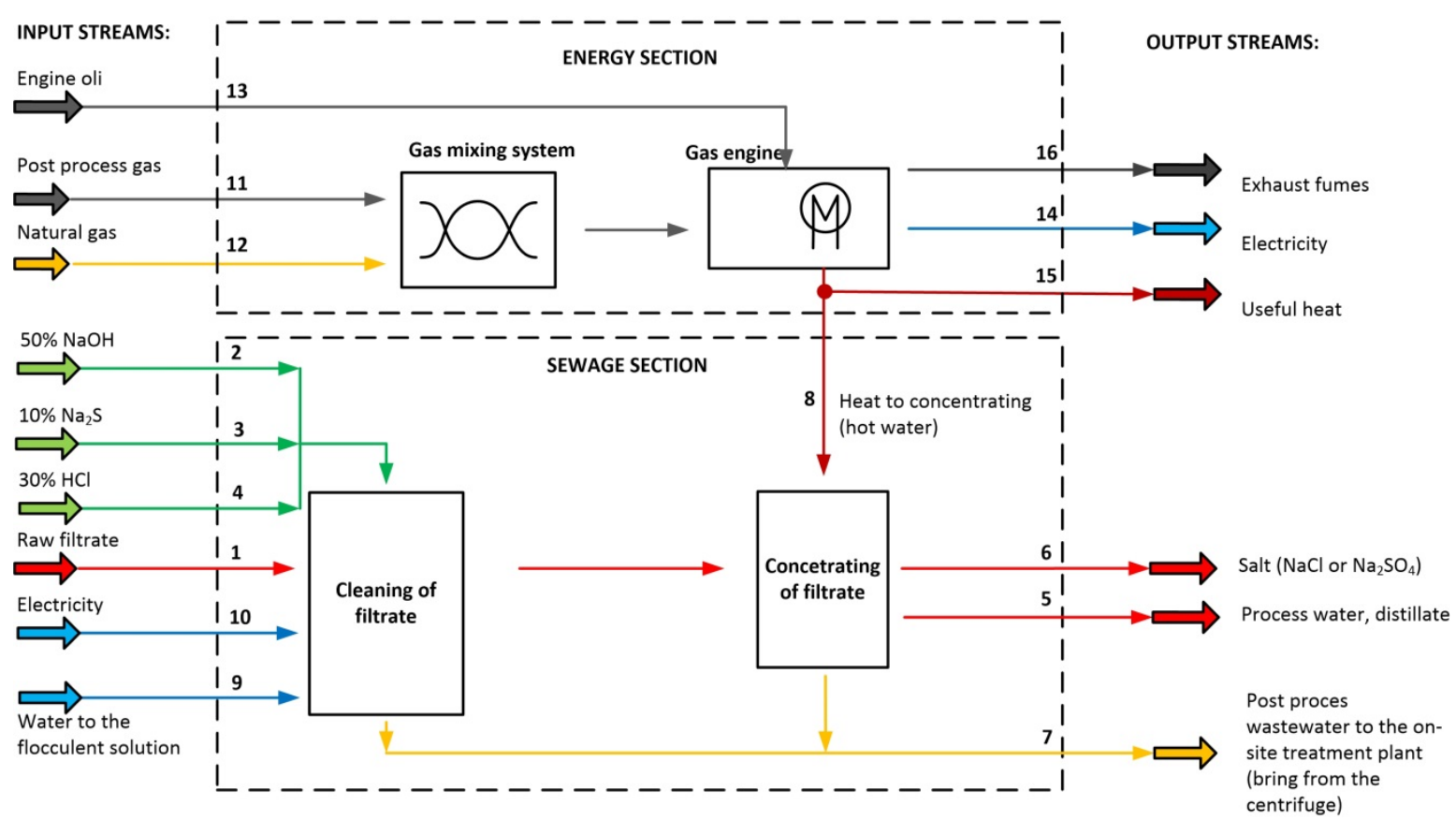

Figure 1. Technological diagram of the RECLEG installation.

In the first phase of the work, on the basis of the obtained results of the study of the post-reduction gas and the wastewater produced in the dust dechlorination node (in the working facilities of the steelworks), the process assumptions for the adopted technological concept were developed. In the second step, the concept of pilot test stands was developed, which made it possible to perform a series of tests on post-reduction gas combustion and wastewater treatment. The verification of the assumptions was made during the research in the RECLEG project on two pilot research installations:

- A pilot installation for the production of electricity and heat from metallurgical waste gas - which included a piston engine with a capacity of about 1.0 MWel;

- A pilot plant for removing salt from industrial wastewater consisting of a node for preliminary purification of the filtrate from heavy metals, and a node for concentrating the purified filtrate - the capacity of the salt removal node is about $60 \mathrm{~kg} /$ day.

The research installations were located on the premises of the steelworks, and the tests were carried out on real post-reduction gases and wastewater. The multi-week series of research tests, as well as the process of optimising the parameters of their work (for example, in terms of achieved efficiency, the operational reliability of individual systems), made it possible to obtain reliable data, among others, for LCA analysis and technology scaling.

\section{Materials and Methods}

The Life Cycle Assessment analysis was performed using the SimaPro 9.0 Analyst software sourced from PRé Sustainability, Amersfoort, The Netherlands, based on the Ecoinvent 3.0 database (Zurich, Switzerland). The environmental impact indicators were calculated in 18 impact categories and 3 damage categories, using the ReCiPe methodology. The ReCiPe is a simplification of a long list of life cycle inventory results that remain in a limited number of indicators. The name ReCiPe is an acronym that represents the names of the institutes responsible for creating this method [21-23]. The methodology was chosen from a number of methodologies, based on the experience and popularity of the chosen tool and the purpose of the analysis [24-27]. The data provided for analysis were obtained from the real object, as described in the first chapter of the article.

Assumptions adopted for the LCA analysis: 
- Electricity production using post-process gas and natural gas in a reciprocating engine will replace production from the current energy mix adopted for Poland (based on coal, and data from the Ecoinvent 3.0 database);

- The exhaust gases are based on those provided by the reciprocating engine;

- The post-process gas defined in the program is based on the data provided;

- The raw filtrate defined in the program is based on the data provided;

- Waste heat was assumed waste heat in a cogeneration engine, for Poland (the data is from Ecoinvent 3.0);

- Other substances and products used in the analysis, taken from the Ecoinvent database;

- Other substances, products or substrates not included in the analysis (not defined, not observed) have a negligible impact, like solid pollutants collected on the gas filter.

The analysis takes into account the full environmental impact, and also takes into account the impact on the aquatic environment, due to the treatment of wastewater in the process. The analysis also takes into account the effects of the production of electricity and heat, as well as post-process gas. The functional unit is 1 year of operation for the RECLEG technology.

The RECLEG technology provides solutions for the sulphide campaign and the oxide campaign, due to the use of different raw materials, such as zinc and lead carriers. In the oxide campaign, $\mathrm{NaCl}$ is the only product in the filtrate purification and concentration process, while additionally $\mathrm{Na}_{2} \mathrm{SO}_{4}$ is produced in the sulphide campaign. The inventoried data are presented in Table 1. Additionally, descriptions for post-process gas, exhaust gas and natural gas were provided, which are necessary for the correct analysis of the entire process, taking into account the detailed parameters of the analysed technology. In Tables 2-4 quantitative data are presented.

Table 1. LCI input data for sulphide and oxide campaigns.

\begin{tabular}{|c|c|c|c|c|}
\hline & Unit & Stream No. & $\begin{array}{c}\text { Oxide } \\
\text { Campaign }\end{array}$ & $\begin{array}{l}\text { Sulphide } \\
\text { Campaign }\end{array}$ \\
\hline Oxide campaign & hour/year & & 7700 & 0 \\
\hline Sulphide campaign & hour/year & & 0 & 7700 \\
\hline Total installation operating time & hour/year & & 7700 & 7700 \\
\hline \multicolumn{5}{|l|}{ Raw material } \\
\hline Raw filtrate & $\mathrm{Mg} /$ year & 1 & $41,854.2$ & $42,456.9$ \\
\hline of which $\mathrm{NaCl}$ & $\mathrm{Mg} /$ year & 1 & 2643.4 & 1987.0 \\
\hline of which $\mathrm{Na}_{2} \mathrm{SO}_{4}$ & $\mathrm{Mg} /$ year & 1 & 313.8 & 1784.9 \\
\hline $50 \% \mathrm{NaOH}$ solution & $\mathrm{Mg} /$ year & 2 & 741.0 & 235.7 \\
\hline $10 \% \mathrm{Na}_{2} \mathrm{~S}$ solution & $\mathrm{Mg} /$ year & 3 & 19.6 & 24.2 \\
\hline $30 \% \mathrm{HCl}$ solution for neutralisation & $\mathrm{Mg} /$ year & 4 & 6.1 & 5.6 \\
\hline \multicolumn{5}{|l|}{ Products from wastewater treatment } \\
\hline Distillate-process water & $\mathrm{Mg} /$ year & 5 & $36,760.0$ & $33,084.0$ \\
\hline $\mathrm{NaCl}$ & $\mathrm{Mg} /$ year & 6 & 2103.2 & 0.0 \\
\hline $\mathrm{Na}_{2} \mathrm{SO}_{4}$ & $\mathrm{Mg} /$ year & 6 & 0.0 & 1251.5 \\
\hline \multicolumn{5}{|l|}{ Waste } \\
\hline Brine from the centrifuge & $\mathrm{Mg} /$ year & 7 & 2003.4 & 7783.7 \\
\hline of which $\mathrm{NaCl}$ & $\mathrm{Mg} /$ year & 7 & 540.2 & 1987.0 \\
\hline of which $\mathrm{Na}_{2} \mathrm{SO}_{4}$ & $\mathrm{Mg} /$ year & 7 & 313.8 & 533.3 \\
\hline \multicolumn{5}{|l|}{ Raw materials and materials } \\
\hline Heat for evaporators (hot water) & MWh/year & 8 & $22,176.0$ & $22,176.0$ \\
\hline Water for flocculant & $\mathrm{Mg} /$ year & 9 & 154.0 & 154.0 \\
\hline Praestol 2540 (Polyacrylamide) & $\mathrm{Mg} /$ year & 9 & 0.4 & 0.4 \\
\hline Electricity & MWh/year & 10 & 1657.0 & 1657.0 \\
\hline Reduced gas & $\mathrm{Mg} /$ year & 11 & 147,070 & 147,070 \\
\hline Natural gas & $\mathrm{Mg} /$ year & 12 & 68,299 & 68,299 \\
\hline Engine oil & $\mathrm{Mg} /$ year & 13 & 22.5 & 22.5 \\
\hline \multicolumn{5}{|l|}{ Products from the processing of reduced gas } \\
\hline Electricity generated in the engine & MWh/year & 14 & 392,700 & 392,700 \\
\hline
\end{tabular}


Table 1. Cont.

\begin{tabular}{ccccc}
\hline & Unit & Stream No. & $\begin{array}{c}\text { Oxide } \\
\text { Campaign }\end{array}$ & $\begin{array}{c}\text { Sulphide } \\
\text { Campaign }\end{array}$ \\
\hline Useful heat & MWh/year & 15 & 355,894 & 355,894 \\
Exhaust gases & Mg/year & 16 & $1,889,580$ & $1,889,580$ \\
\hline
\end{tabular}

Table 2. Post-process gas parameters in the RECLEG technology process.

\begin{tabular}{ccc}
\hline Ingredient & Quantity & Unit \\
\hline $\mathrm{O}_{2}$ & 0.00 & $\%$ \\
$\mathrm{CO}_{2}$ & 6.30 & $\%$ \\
Central heating & 31.80 & $\%$ \\
$\mathrm{~N}_{2}$ & 60.10 & $\%$ \\
$\mathrm{CH}_{4}$ & 0.20 & $\%$ \\
$\mathrm{H}_{2}$ & 1.60 & $\%$ \\
$\mathrm{H}_{2} \mathrm{O}$ & 0.00 & $\%$ \\
$\mathrm{Mz}$ & 28.85 & $\mathrm{~kg} / \mathrm{kmol}$ \\
$\mathrm{Wd}$ & 4.27 & $\mathrm{MJ} / \mathrm{Nm}^{3}$ \\
\hline
\end{tabular}

Table 3. Exhaust gas parameters in the RECLEG technology process.

\begin{tabular}{ccc}
\hline Ingredient & Quantity & Unit \\
\hline $\mathrm{O}_{2}$ & 4.37 & $\%$ \\
$\mathrm{CO}_{2}$ & 9.32 & $\%$ \\
Central heating & 0.00 & $\%$ \\
$\mathrm{~N}_{2}$ & 73.60 & $\%$ \\
$\mathrm{CH}_{4}$ & 0.00 & $\%$ \\
$\mathrm{H}_{2}$ & 0.00 & $\%$ \\
$\mathrm{H}_{2} \mathrm{O}$ & 12.71 & $\%$ \\
$\mathrm{C}_{2} \mathrm{H}_{6}$ & 0.00 & $\%$ \\
$\mathrm{Mz}$ & 28.40 & $\mathrm{~kg} / \mathrm{kmol}$ \\
\hline
\end{tabular}

Table 4. Exhaust gas parameters in the RECLEG technology process.

\begin{tabular}{ccc}
\hline Ingredient & Quantity & Unit \\
\hline $\mathrm{CO}_{2}$ & 0.18 & $\%$ \\
$\mathrm{~N}_{2}$ & 0.60 & $\%$ \\
$\mathrm{CH}_{4}$ & 96.95 & $\%$ \\
$\mathrm{C}_{2} \mathrm{H}_{6}$ & 2.26 & $\%$ \\
$\mathrm{Mz}$ & 16.40 & $\mathrm{~kg} / \mathrm{kmol}$ \\
$\mathrm{Wd}$ & 36.13 & $\mathrm{MJ} / \mathrm{Nm}^{3}$ \\
\hline
\end{tabular}

\section{Results}

The analysis was carried out using the SimaPro 9.0 software sourced from PRé Sustainability, Amersfoort, The Netherlands, using the ReCiPe methodology, based on the Ecoinvent 3.0 database sourced from Ecoinvent, Zurich, Switzerland [28-31]. The results of the LCA analysis are presented in Sections 3.1 and 3.2.

\subsection{Mid-Point Analysis}

In mid-point LCA analysis, the environmental impact was calculated at eighteen detailed intermediate points, which are relatively accurate and quantitatively show the impact on individual categories; however, these are more difficult for general interpretation due to the wide scope of analysis [32-34]. The results are shown in Figures 2 and 3. 


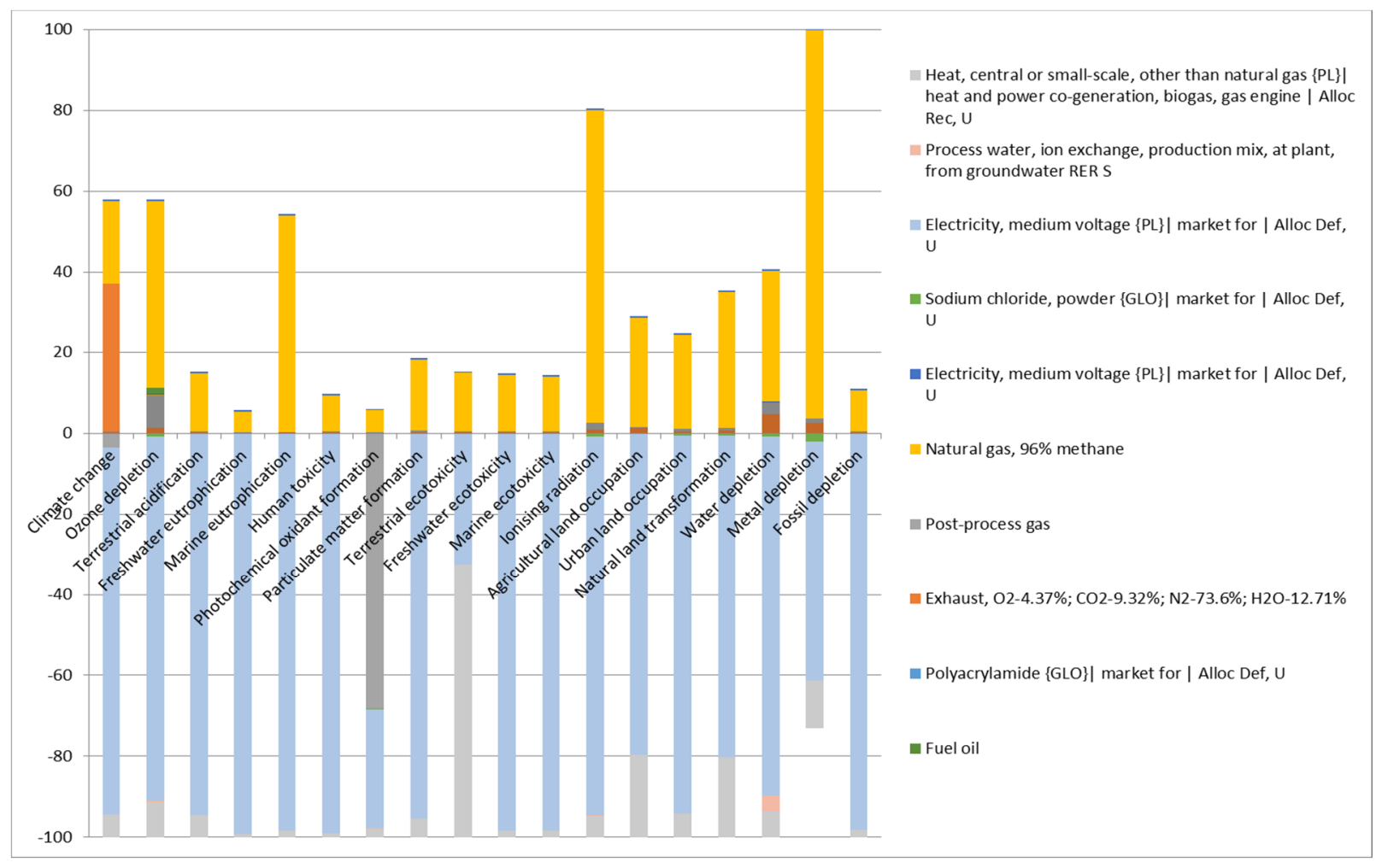

Figure 2. Percentage distribution of the LCA analysis results of the RECLEG technology for the oxide campaign.

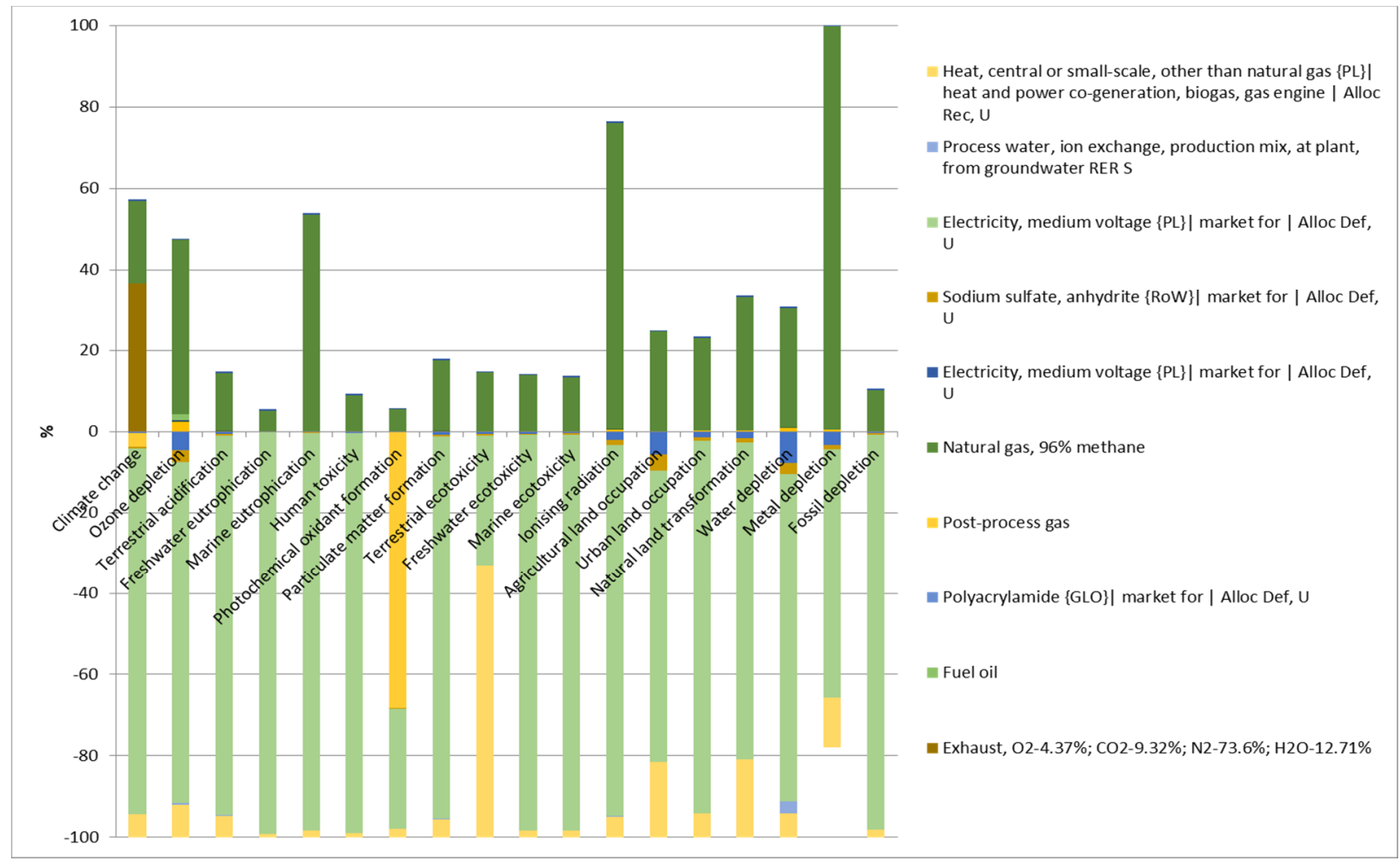

Figure 3. Percentage distribution of the LCA analysis results of the RECLEG technology for the sulphide campaign. 


\subsection{End-Point Analysis}

In order to make the LCA results easier to interpret, one can base the damage categories on the so-called end-point analysis. In this area, three impact categories are defined in the ReCiPe methodology: human health, ecosystem and natural resources. These categories are the result of weight conversions from all 18 categories of impact on the categories of damage. They can help in the overall interpretation of the analysis [32-34]. For the visualisation of results, the oxide campaign and sulphide campaign are presented in diagrams in Figures 4-6.

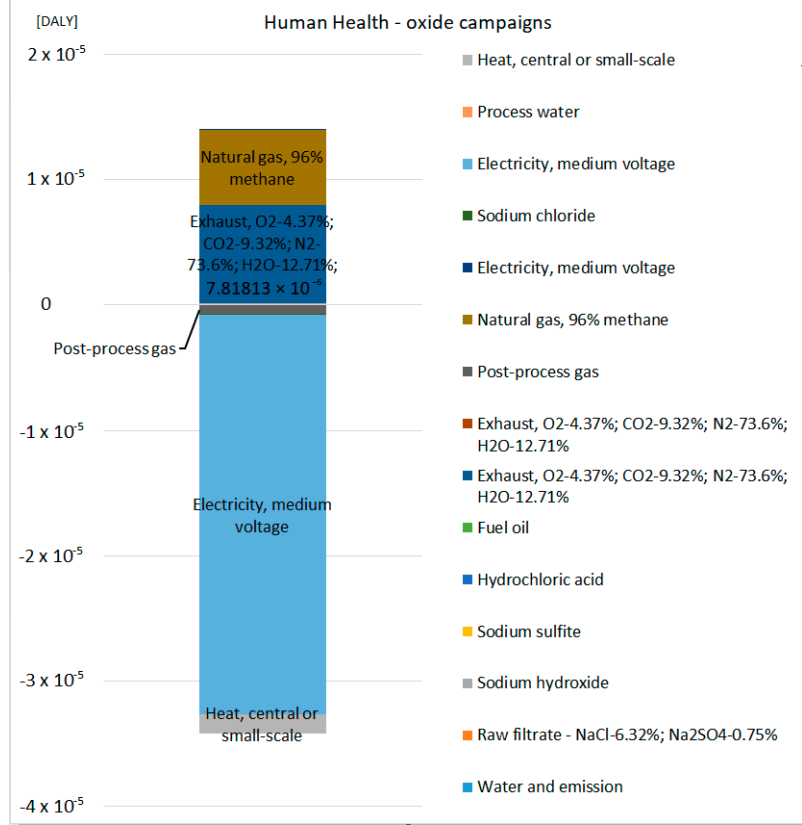

(a)

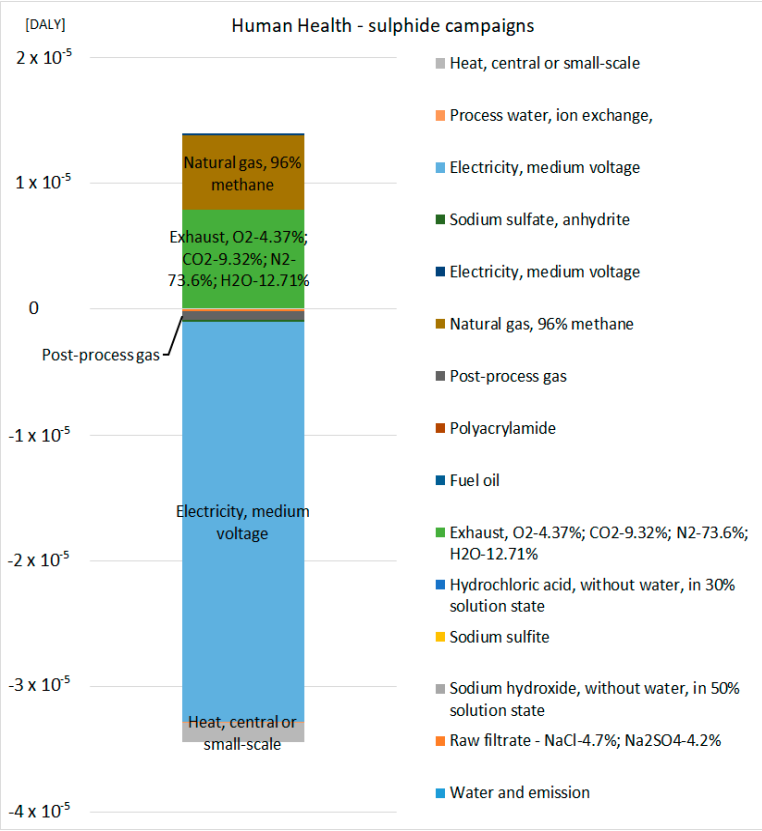

(b)

Figure 4. Results of the LCA analysis at the end-point analysis in the human health category for the oxide (a) and sulphide (b) campaigns.

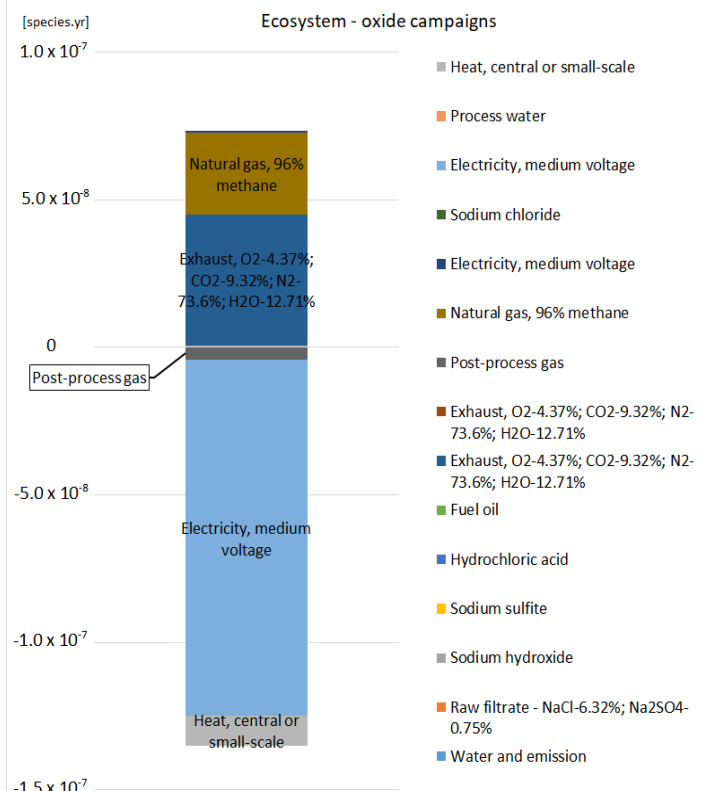

(a)

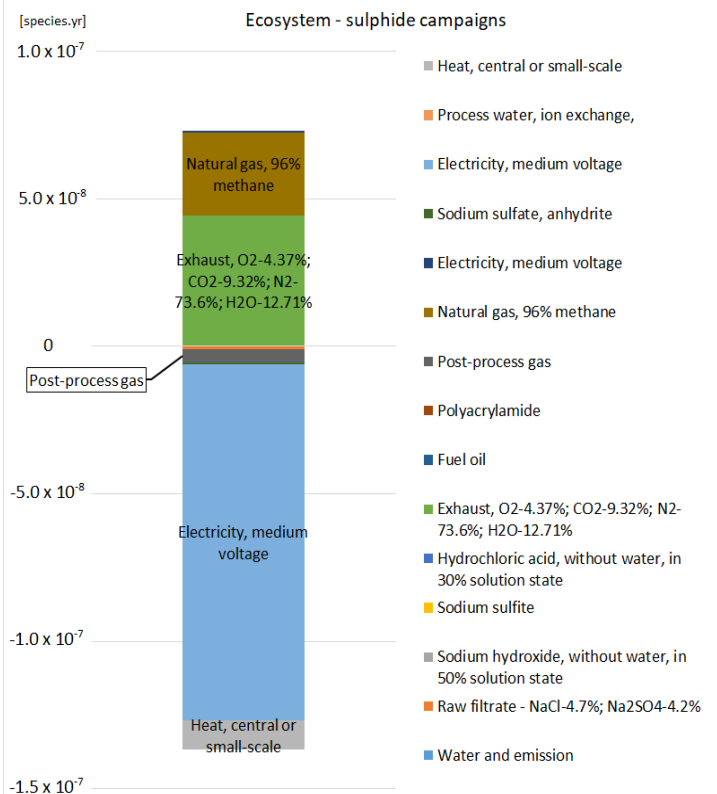

(b)

Figure 5. Results of the LCA analysis at the end-point analysis in the ecosystem category for the oxide (a) and sulphide (b) campaigns. 


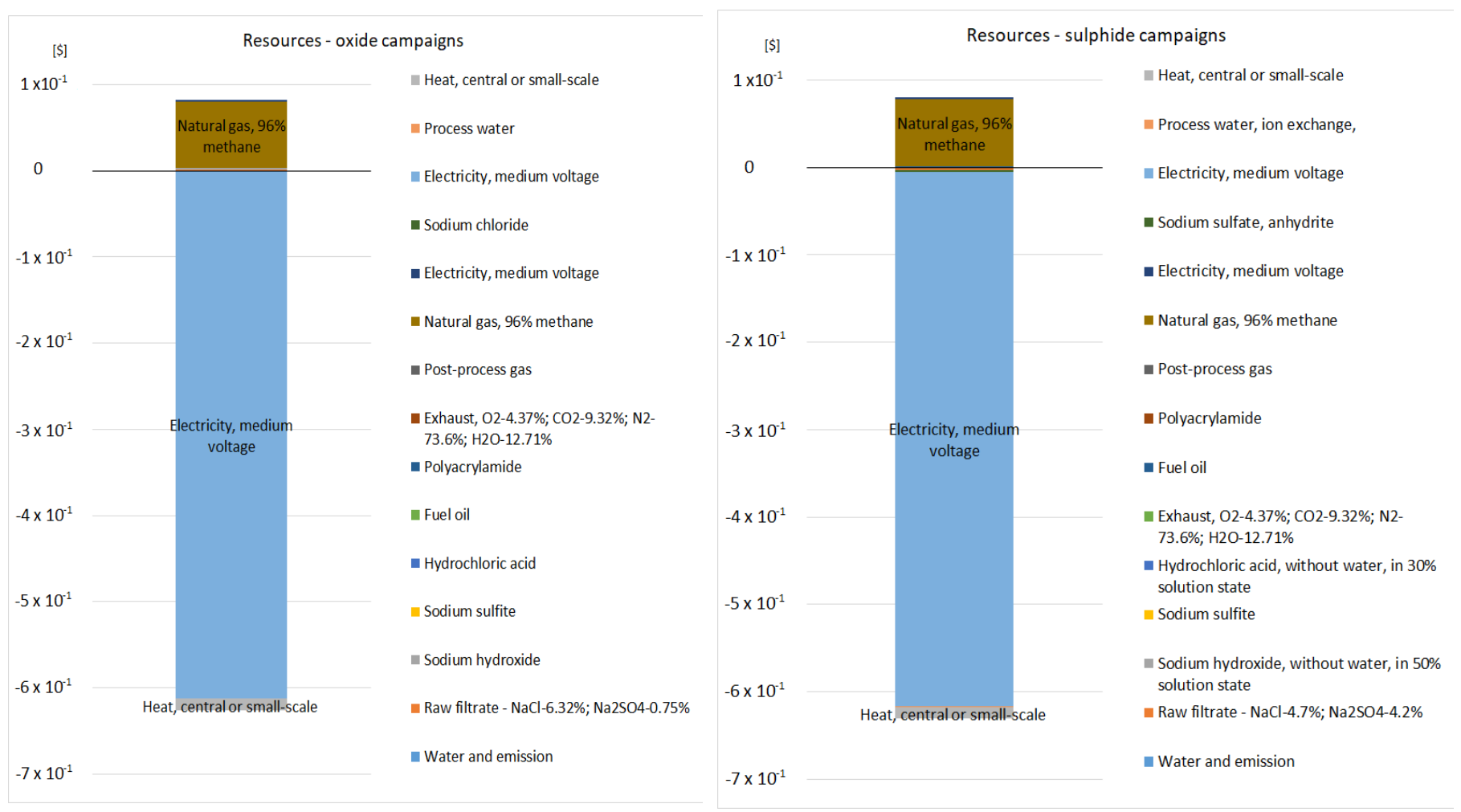

(a)

(b)

Figure 6. Results of the LCA analysis at the end-point analysis in the resources category for the oxide and sulphide campaigns.

From Figures 4-6, it can be concluded that, for both the sulphide and oxygen campaigns, the results are very similar. In the human health category, the greatest negative impact is from exhaust gases and natural gas, however the positive impact in these categories is greater due to the production of electricity. In the ecosystem category, the results are similar. The large amount of electricity produced, in an environmental context, minimises the impact of other products taken into the process.

In the natural resources category, methane has the greatest negative impact, because by using it, we exhaust resources irretrievably. Nonetheless, thanks to the use of reduced gas to produce electricity, we save coal—on which the Polish energy mix is based-and we can observe that the positive impact is over 5 times greater than the negative impact of methane on the entire process. Therefore, the whole analysis shows that the RECLEG technology has a positive impact, despite the fact that different products are used for individual processes and that the technology is supported through the use of methane [34-36].

To compare the environmental impact of the RECLEG technology directly with the production of electricity in the Polish energy mix, the entire impact was converted into $1 \mathrm{MWh}$. The results are summarised in Table 5.

The introduction of specific units such as DALY, species.yr, or dollars into the analysis should also be clarified. This is due to the framework proposed in the ReCiPe methodology, where the areas of protection are human health, quality of ecosystems and resource scarcity. Units are proposed for each of these areas. Human health should be expressed in DALYs (Disability Adjusted Years of Life) which represents the years that have been lost or if the person is disabled due to illness or accident. For the second area, it is proposed to use the local relative species loss expressed in the number of species per year. The unit of resource scarcity is dollars (\$). They represent additional costs related to the future extraction of mineral and fossil resources [37]. 
Table 5. The overall impact on the environment in three damage categories, calculated into $1 \mathrm{MWh}$ of electricity using the RECLEG technology and the Polish energy mix.

\begin{tabular}{cccccc}
\hline No. & Damage Category & Unit & $\begin{array}{c}\text { Sulphide } \\
\text { Campaign }\end{array}$ & Oxide Campaign & PL Energy Mix \\
\hline 1. & Human Health & DALY & $-5.20 \times 10^{-11}$ & $-5.12 \times 10^{-11}$ & $7.10 \times 10^{-7}$ \\
2. & Ecosystem & species.yr & $-1.63 \times 10^{-13}$ & $-1.57 \times 10^{-13}$ & $2.69 \times 10^{-9}$ \\
3. & Natural Resources & $\$$ & $-1.40 \times 10^{-6}$ & $-1.38 \times 10^{-6}$ & $1.36 \times 10^{-2}$ \\
\hline
\end{tabular}

The results of the LCA should be analysed according to the rule: negative values are treated as a positive impact on the environment, while positive values are treated as a negative impact. In each of the categories, a positive impact on the environment can be observed, and also converted into $1 \mathrm{MWh}$, both for the sulphide and oxide campaigns involving the RECLEG technology. Compared to coal, the value of the indicators in the presented calculations is positive; for coal in each indicator, it is a positive value, and therefore negative for the environment.

\section{Discussion}

The LCA analysis confirmed that RECLEG technology has a positive impact on the environment due to:

- Electricity generation using waste reduced gas, which replaces electricity production for the mix in Poland, mainly based on coal;

- The use of waste heat in the wastewater treatment process, as well as the production of this heat, which can be used for other processes;

- The production of salt, which can be used in further processes, is the result of the purification of the raw waste filtrate;

- The recycling of post-process water in the form of clean water to a zinc smelter, which has a beneficial effect on the impact categories related to the water environment.

This is an example showing the possibility of using waste energy sources to convert energy into electricity, resulting in a positive environmental effect. It can also be added that not only renewable sources can be a source of electricity, but also thanks to the single use of various possibilities, it is possible to reduce the negative environmental impact of the coal sector, which is the basic source of energy in Poland. Research on the assessment of technological solutions increasing energy efficiency in sewage treatment plants was carried out, among others, by [12-14]. The results allowed for the selection of the optimal solution, or the identification of weak points in the technology. Nevertheless, these installations differed from the ones presented in this article. In the next stage of works, further tests for the dedicated solution are planned for a real facility.

Due to the lack of specification with the hydrated desalination sludge, as well as its expected negligible effect, due to its very small amount, its impact was not taken into account in the LCA analysis. It was assumed that the reduced gas that was used in production has no negative impact because the technology uses it and transforms it into energy. Under normal conditions, it is burned in a flare, and the exhaust gases released have had a greater impact on the environment. Therefore, in the analysis, it should be emphasised that the positive impact of RECLEG technology may be even greater than calculated. However, due to the lack of data on exhaust gases, it is not possible to precisely quantify this impact before the introduction of the technology. By contrast, the replacement effect is positive.

Author Contributions: Conceptualization, M.B., T.I. and K.P.; methodology, M.B. and T.I.; software, M.B.; validation, M.B., T.I., K.P., M.Ś., M.S. and A.C.; formal analysis, M.B., T.I., K.P., M.Ś., M.S. and A.C.; investigation, M.B., T.I., K.P., M.Ś., M.S. and A.C.; resources, T.I., M.Ś., M.S., A.C. and A.W.; data curation, M.B. and T.I.; writing—original draft preparation, M.B., T.I., K.P., M.Ś., M.S., A.C. and A.W.; 
writing-review and editing, M.B., T.I. and A.W.; visualization, M.B., T.I. and A.W.; supervision, M.B., T.I. and K.P. All authors have read and agreed to the published version of the manuscript.

Funding: This research was funded by subsidies granted (08/030/BK_22/0101) for the year 2022 to the Department of Technology and Installations for Waste Management, Silesian University of Technology.

Institutional Review Board Statement: Not applicable.

Informed Consent Statement: Not applicable.

Data Availability Statement: Not applicable.

Acknowledgments: This work was supported by the "Effective generation of electric power from metallurgical waste gases with a simultaneous reduction of chlorine ion emissions into the environment"RECLEG project co-financed by the European Regional Development Fund under the Operational Programme Smart Growth (Contract no.: POIR.01.02.00-00-0170/16) within Sectoral Programme INNOSTAL.

Conflicts of Interest: The authors declare no conflict of interest.

\section{References}

1. United Nations. Transforming Our World: The 2030 Agenda for Sustainable Development; United Nations: Paris, France, 2015; Available online: https://sustainabledevelopment.un.org/post2015/transformingourworld/publication (accessed on 15 November 2020).

2. European Union. Closing the Loop-An EU Action Plan for the Circular Economy. Available online: https://eur-lex.europa.eu/ legal-content/EN/TXT/?uri=CELEX:52015DC0614 (accessed on 17 November 2021).

3. Poranek, N.; Łaźniewska-Piekarczyk, B.; Czajkowski, A.; Pikoń, K. Circular Economy for Municipal Solid Waste Incineration Bottom Ash (MSWIBA) Management in Mortars with CSA and CEM I, MSWIBA Glassy Phase, and DTG. Energies 2022, 15, 135. [CrossRef]

4. Poranek, N.; Łaźniewska-Piekarczyk, B.; Czajkowski, A.; Pikoń, K. Possibilities of Management of Fly Ash from Municipal Solid Waste Incineration Plant in Building Industry in the Circular Economy. IOP Conf. Ser. Mater. Sci. Eng. 2021, 1203. [CrossRef]

5. Miśkiewicz, R. Efficiency of Electricity Production Technology from Post-Process Gas Heat: Ecological, Economic and Social Benefits. Energies 2020, 13, 6106. [CrossRef]

6. Bjørnbet, M.M.; Vildåsen, S.S. Life Cycle Assessment to Ensure Sustainability of Circular Business Models in Manufacturing. Sustainability 2021, 13, 11014. [CrossRef]

7. Alexandrov, G.A.; Ames, D. Technical assessment and evaluation of environmental models and soft-ware: Letter to the Editor. Environ. Model. Soft. 2011, 26, 328-336. [CrossRef]

8. Górzyński, J. Podstawy Analizy Środowiskowej Wyrobów i Obiektów (Basics of Environmental Analysis of Products and Objects); Wydawnictwa Naukowo-Techniczne: Warsaw, Poland, 2007.

9. Bogacka, M.; Pikon, K. Best Practice in Environmental Impact Evaluation Based on LCA-Methodologies Review, Geo Conference on Ecology, Economics, Education and Legislation, vol II Book Serie. In Proceedings of the International Multidisciplinary Scientific Geo Conference-SGEM, Albena, Bulgaria, 17-26 June 2014; pp. 101-108.

10. Bernal, D.C.; Muñoz, E.; Manente, G.; Sciacovelli, A.; Ameli, H.; Gallego-Schmid, A. Environmental Assessment of Latent Heat Thermal Energy Storage Technology System with Phase Change Material for Domestic Heating Applications. Sustainability 2021, 13, 11265. [CrossRef]

11. Noël, J.A.; Allred, P.M.; White, M.A. Life cycle assessment of two biologically produced phase change materials and their related products. Int. J. Life Cycle Assess. 2015, 20, 367-376. [CrossRef]

12. Smita, R.; Vikrant, B.; Chelikani, S.; Sangwan, K.S. Waste Water Treatment Plant Life Cycle Assessment: Treatment Process to Reuse of Water. Procedia CIRP 2017, 61,761-766.

13. Szulc, P.; Kasprzak, J.; Dymaczewski, Z.; Kurczewski, P. Life Cycle Assessment of Municipal Wastewater Treatment Processes Regarding Energy Production from the Sludge Line. Energies 2021, 14, 356. [CrossRef]

14. Skoczko, I.; Szatyłowicz, E.; Horysz, M.; Malinowski, Ł.; Tunc, A. Life cycle assessment of industrial and urban wastewater treatment plant. Econ. Environ. Stud. 2016, 1, 37.

15. Corominas, L.; Byrne, D.M.; Guest, J.S.; Hospido, A.; Roux, P.; Shaw, A.; Short, M.D. The application of life cycle assessment (LCA) to wastewater treatment: A best practice guide and critical review. Water Res. 2020, 184, 116058. [CrossRef] [PubMed]

16. Renou, S.; Thomas, J.S.; Aoustin, E.; Pons, M.N. Influence of impact assessment methods in wastewater treatment LCA. J. Clean. Prod. 2008, 16, 1098-1105. [CrossRef]

17. Parra-Saldivar, R.; Bilal, M.; Iqbal, H.M.N. Life cycle assessment in wastewater treatment technology. Curr. Opin. Environ. Sci. Health 2020, 13, 80-84. [CrossRef]

18. Rebello, T.A.; Roque, R.P.; Gonçalves, R.F.; Calmon, J.L.; Queiroz, L.M. Life cycle assessment of urban wastewater treatment plants: A critical analysis and guideline proposal. Water Sci. Technol. 2020, 83, 501-514. [CrossRef] [PubMed] 
19. Hertwich, E.G.; Thomas, B.; Evert, A.; Suh, A.; Heath, S.; Bergesen, G.; Ramírez, J.; Vega-Coloma, A.; Shi, M. Integrated life-cycle assessment of electricity-supply scenarios confirms global environmental benefit of low-carbon technologies. Proc. Natl. Acad. Sci. USA 2014, 112, 6277-6282. [CrossRef] [PubMed]

20. Rödger, J.-M.; Beier, J.; Schönemann, M.; Schulze, C.; Thiede, S.; Bey, N.; Herrmann, C.; Hauschild, M.Z. Combining Life Cycle Assessment and Manufacturing System Simulation: Evaluating Dynamic Impacts from Renewable Energy Supply on Product-Specific Environmental Footprints. Int. J. Precis. Eng. Manuf. Technol. 2021, 8, 1007-1026. [CrossRef]

21. Bengtsson, J.; Howard, N. A Life Cycle Impact Assessment, Part 1: Classification and Characterization; BPIC/ICIP Life Cycle Inventory Project, Building Products Innovation Council (BPIC) and AusIndustry: Sydney, Australia, 2010.

22. For More Information, Appendix A-Reference materials, Sustainability \& Sustainable Business. In Berkshire Encyclopedia of Sustainability; Berkshire Publishing Group: Great Barrington, MA, USA, 2009-2011; Chapter 10; Volumes 1-10.

23. Bilitewski, B.; Hardtle, G.; Marek, K. Podręcznik Gospodarki Odpadami. Teoria i Praktyka (Waste Management Manual. Theory and Practice); Wyd. Seidel Przywecki: Warsaw, Poland, 2006.

24. EMEP/EEA Air Pollutant Emission Inventory Guidebook 2013, Technical Report No 12/2013. Available online: http:/ / www.eea. europa.eu/ / publications / emep-eea-guidebook-2013 (accessed on 10 December 2021).

25. EMEP/EEA Air Pollutant Emission Inventory Guidebook 2016, Small Combustion 2016. Available online: http:/ www.eea. europa.eu/ / publications/Small-combustion-2016 (accessed on 12 December 2021).

26. Emissions Factors \& AP 42, Compilation of Air Pollutant Emission Factors, AP 42, Fifth Edition, Volume 1: Stationary Point and Area Sources, US EPA. Available online: http:/ / www.epa.gov/ttnchie1/ap42/ (accessed on 14 December 2021).

27. EPA. Emissions from Waste Incineration. In Good Practice Guidance and Uncertainty Management in National Greenhouse Gas Inventories; Report Accepted by the IPCC Plenary at Its 16th Session Held in Montreal, Canada, 1-8 May 2000; Available online: https: / / www.ipcc-nggip.iges.or.jp/public/gp/english/ (accessed on 31 December 2021).

28. Goedkoop, M. ReCiPe 2008 a Life Cycle Impact Assessment Method which Comprises Harmonised Category Indicators at The Midpoint and The Endpoint Level, Report, Ruimte en Milieu, Ministerie van Volkshuisvesting, Ruimtelijke Ordening en Milieubeheer. Holandia. 2009. Report Published in the Framework of the ReCiPe Project. Available online: http://www.lciarecipe.net (accessed on 12 December 2021).

29. de Bruijn, H.; van Duin, R.; Huijbregts, M.A.J.; Guinee, J.B.; Gorree, M.; Heijungs, R.; Huppes, G.; Kleijn, R.; de Koning, A.; van Oers, L.; et al. Handbook on Life Cycle Assessment. Operational Guide to the ISO Standards; Eco-Efficiency in Industry and Science; Kluwer Academic Publishers: Amsterdam, The Netherlands, 2004; Volume 7.

30. European Commission; Joint Research Centre; Institute for Environment and Sustainability. ILCD Handbook. Analysing of Existing Environmental Impact Assessment Methodologies for Use in Life Cycle Assessment; Institute for Environment and Sustainability, Joint Research Centre, European Commission: Ispra, Italy, 2010.

31. International Energy Agency Optimising Russian Gas. Reform and Climate Policy. OECD/IEA, 2006, Dosteepny w Internecie: Stan na Dzień 25.05.2013 r. Available online: www.iea.org/textbase/npsum/opt_russ_gas.pdf (accessed on 12 December 2021).

32. ISO 14040:2006; Environmental Management-Life Cycle Assessment-Principles and Framework. International Organization for Standardization: Geneva, Switzerland, 2006.

33. PN-EN ISO 14042; Zarządzanie Środowiskowe-Ocena Cyklu Życia-Ocena Wpływu Cyklu Życia (Environmental ManagementLife Cycle Assessment-Life Cycle Impact Assessment). PKN (Polski Komitet Normalizacyjny): Warsaw, Poland, 2000.

34. PN-EN ISO 14043; Zarządzanie Środowiskowe-Ocena Cyklu Życia-Interpretacja Cyklu Życia (Environmental Management-Life Cycle Assessment-Life Cycle Interpretation). PKN (Polski Komitet Normalizacyjny): Warsaw, Poland, 2000.

35. Poland's informative inventory report 2016. In Submission under the UN ECE Convention on Long-Range Transboundary Air Pollution; IOŚ-PIB KOBIZE: Warsaw, Poland, 2016.

36. Konieczyński, J. (Ed.) Właściwości Pyłu Respirabilnego Emitowanego z Wybranych Instalacji (Properties Of Respirable Dust Emitted From Selected Installations); Instytut Podstaw Inżynierii Środowiska Polskiej Akademii Nauk. Pod redakcją: Zabrze, Poland, 2010.

37. Huijbregts, M.A.J.; Steinmann, Z.J.N.; Elshout, P.M.F.; Stam, G.; Verones, F.; Vieira, M.; Zijp, M.; Hollander, A.; van Zelm, R. ReCiPe2016: A harmonised life cycle impact assessment method at midpoint and endpoint level. Int. J. Life Cycle Assess 2017, 22, 138-147. [CrossRef] 